[Article]

\title{
高指数晶面结构氧化铁化学链燃烧反应活性及深层还原反应机理
}

\author{
覃 吴 ${ }^{*}$ 林常枫 龙东腾 肖显斌 董长青 \\ (华北电力大学可再生能源学院, 生物质发电成套设备国家工程实验室, 北京 102206)
}

\begin{abstract}
摘要: 采用密度泛函理论计算和实验研究形貌可控制备氧化铁作为高效载氧体用于化学链燃烧的可行性. 首 先从理论上对比分析 $\mathrm{Fe}_{2} \mathrm{O}_{3}$ 高指数晶面[104]和低指数晶面[001]的反应活性及深层还原反应机理. 表面反应结 果显示, $\mathrm{Fe}_{2} \mathrm{O}_{3}[104]$ 氧化 $\mathrm{CO}$ 的反应活性远高于 $\mathrm{Fe}_{2} \mathrm{O}_{3}[001], \mathrm{Fe}_{2} \mathrm{O}_{3}[104]$ 被还原成为低价的铁氧化物或单质, 这 些低价的铁氧化物或单质可被 $\mathrm{O}_{2}$ 氧化再生. 载氧体和 $\mathrm{CO}$ 深层反应结果显示 $\mathrm{Fe}_{2} \mathrm{O}_{3}[104]$ 可被 $\mathrm{CO}$ 彻底还原成 $\mathrm{Fe}$ 单质, $\mathrm{Fe}_{2} \mathrm{O}_{3}$ [104]释放氧能力强, 反应活性高; 而 $\mathrm{Fe}_{2} \mathrm{O}_{3}[001]$ 还原到一定程度后反应能垒高, 抑制表面进一步 还原, 释放氧能力有限. 最后, 实验结果进一步证明了 $\mathrm{Fe}_{2} \mathrm{O}_{3}[104]$ 作为载氧体用于化学链燃烧的高反应活性及 稳定性.
\end{abstract}

关键词: 燃烧; 表面; 吸附; $\mathrm{Fe}_{2} \mathrm{O}_{3}$; 密度泛函理论

中图分类号: 0641

\section{Reaction Activity and Deep Reduction Reaction Mechanism of a High Index Iron Oxide Surface in Chemical Looping Combustion}

\author{
QIN Wu* LIN Chang-Feng ～LONG Dong-Teng XIAO Xian-Bin DONG Chang-Qing \\ (National Engineering Laboratory for Biomass Power Generation Equipment, School of Renewable Energy Engineering, \\ North China Electric Power University, Beijing 102206, P. R. China)
}

\begin{abstract}
The possibility of morphological control of iron oxide as an oxygen carrier for chemical looping combustion was investigated using density functional theory and experiment. First, we calculated the reactivity of $\mathrm{Fe}_{2} \mathrm{O}_{3}$ with high-index facets [104] and low-index facets [001], as well as the deep reduction reaction mechanism of these two facets. Surface reaction results show that the activity of $\mathrm{Fe}_{2} \mathrm{O}_{3}[104]$ for oxidizing $\mathrm{CO}$ is greater than that of $\mathrm{Fe}_{2} \mathrm{O}_{3}[001]$. $\mathrm{Fe}_{2} \mathrm{O}_{3}[104]$ was reduced into iron oxide at lower oxidation state or into iron, which could then be regenerated after being oxidized by $\mathrm{O}_{2}$. The deep reduction reaction mechanism between oxygen carrier and $\mathrm{CO}$ shows that $\mathrm{Fe}_{2} \mathrm{O}_{3}[104]$ can be completely reduced into $\mathrm{Fe}$, and $\mathrm{Fe}_{2} \mathrm{O}_{3}[104]$ exhibits high oxygen transfer ability. However, $\mathrm{Fe}_{2} \mathrm{O}_{3}[001]$ can only be reduced to a limited extent, with a high energy barrier preventing further reduction, while it also exhibits limited oxygen transfer capacity. Results of experiments further verify the high reactivity and stability of $\mathrm{Fe}_{2} \mathrm{O}_{3}[104]$.
\end{abstract}

Key Words: Combustion; Surface; Adsorption; $\mathrm{Fe}_{2} \mathrm{O}_{3} ;$ Density functional theory

\section{Introduction}

Chemical looping combustion (CLC) has received great attraction for its efficient use of energy and inherent separation of $\mathrm{CO}_{2}{ }^{1-3} \mathrm{CLC}$ is a promising technology that produces heat and energy using oxygen carrier (OC) to supply oxygen instead of air for combustion of fuel, which results in the generation of a sequestration-ready stream of $\mathrm{CO}_{2}$ that is not diluted with $\mathrm{N}_{2}$ or flue gas and also reduces $\mathrm{NO}_{x}$ emissions. ${ }^{4-10}$ Fig. 1 shows the principle

Received: October 13, 2014; Revised: February 6, 2015; Published on Web: February 6, 2015.

"Corresponding author. Email: qinwugx@126.com; Tel: +86-10-61772457.

The project was supported by the National Natural Science Foundation of China (51106051), 111 Project, China (B12034), and Fundamental

Research Funds for the Central Universities, China (2014MS36, 2014ZD14).

国家自然科学基金(51106051), 111 计划(B12034)和中央高校基金(2014MS36, 2014ZD14)资助项目

(c) Editorial office of Acta Physico-Chimica Sinica 


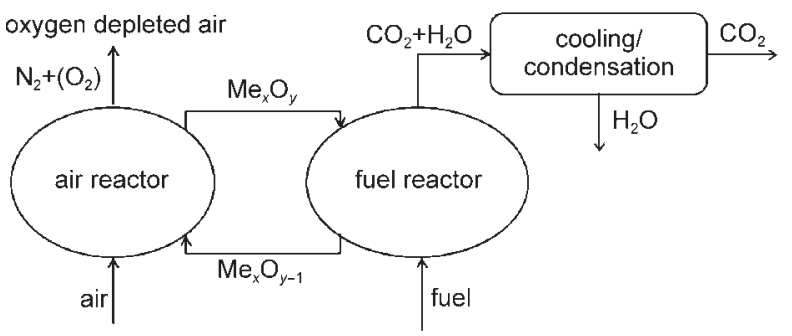

Fig.1 Principle of chemical-looping combustion Me: metal

of CLC.

OC acts as one of the most important factors deciding the efficiency of CLC. Till now, many OCs mainly including the oxides of $\mathrm{Fe}, \mathrm{Ni}, \mathrm{Co}, \mathrm{Cu}, \mathrm{Mn}$, and $\mathrm{Cd}$, have been developed for CLC. Among these OCs, $\mathrm{NiO}$ exhibits high reactivity but thermodynamic limitation and potential carcinogenic tendency of $\mathrm{NiO},{ }^{11}$ $\mathrm{CuO}$ shows exothermic characteristic but low melting point and thus is low resistance to sintering, ${ }^{12} \mathrm{CoO}$ shows satisfactory reactivity and oxygen transfer capacity but high cost, ${ }^{13} \mathrm{Fe}_{2} \mathrm{O}_{3}$ becomes the candidate for CLC process recently due to its environmentally harmlessness, high oxygen capacity, good mechanical strength, and low price. ${ }^{14}$ However, enhancing the oxygen transfer capacity and reactivity of $\mathrm{Fe}_{2} \mathrm{O}_{3}$ becomes urgent problem.

Loaded $\mathrm{Fe}_{2} \mathrm{O}_{3}$ and combined iron based $\mathrm{OC}$ have received great interest for their enhanced reactivity, avoidance of carbon deposition, and good repeatability. ${ }^{15-26}$ But the application of these compounds in CLC systems may not be feasible due to expensive production cost. Recently, controlled synthesis of metal oxide with a large percentage of certain exposed facets causes researcher's attention, owing to their scientific importance associated with highly reactive surfaces. ${ }^{27,28}$ The surface energies of hematite calculated based on density functional theory (DFT) for [001], [101], and [104] facets are 1.146, 1.308, $1.453 \mathrm{~J} \cdot \mathrm{m}^{-2}$, respectively, ${ }^{29}$ which shows that surface energy of the [104] facet is higher than those of [001] and [101] facets. Single crystals of hematite with exposed [104] facets have been prepared for potential application as carbon-alternative anode materials for lithium ion batteries, showing high capacity, improved cyclability, and good rate performance. ${ }^{30}$ The unique $\alpha-\mathrm{Fe}_{2} \mathrm{O}_{3}$ crystals with [104] high-index facets are highly advantageous for gas sensors with high performance. ${ }^{31}$ Single crystals of hematite with nearly $100 \%$ exposed [012] facets show improved photocatalytic properties over nanoplates with dominant [001] facets. ${ }^{32}$

$\mathrm{Fe}_{2} \mathrm{O}_{3}$ with high-index facets shows a noticeable catalytic activity. However, differing from catalytic reaction course, $\mathrm{Fe}_{2} \mathrm{O}_{3}$ is gradually reduced and structurally destroyed during CLC process. Whether such high index $\mathrm{Fe}_{2} \mathrm{O}_{3}$ surface is active enough for fuel CLC and whether the reduced surface can be regenerated remain unknown. In addition, the reaction mechanism between fuel molecule and the high index $\mathrm{Fe}_{2} \mathrm{O}_{3}$ surface, especially the deep reduction reaction mechanism of the high index $\mathrm{Fe}_{2} \mathrm{O}_{3}$ surface, has not been investigated before. To address these problems, we compared the electronic properties, surface reaction activity, oxygen transfer, and deep reduction of the high index $\mathrm{Fe}_{2} \mathrm{O}_{3}$ surface [104] with those of the low index $\mathrm{Fe}_{2} \mathrm{O}_{3}$ surface [001], one of the dominant growth faces of the natural hematite. ${ }^{33}$ Then we experimentally verified the enhanced performance and re- use property of the high index $\mathrm{Fe}_{2} \mathrm{O}_{3}$ surface.

\section{Experimental and computational details}

\subsection{Preparation and chemical looping combustion}

According to the reported method, ${ }^{31} 5.38 \mathrm{~g} \mathrm{FeCl}_{3} \cdot 6 \mathrm{H}_{2} \mathrm{O}(\mathrm{AR}$, Sinopharm Chemical Reagent Beijing Co., Ltd.) and $5.82 \mathrm{~g}$ urea (AR, Sinopharm Chemical Reagent Beijing Co., Ltd.) were dissolved in $200 \mathrm{~mL}$ of distilled water to form a clear yellow solution, and then appropriate amount of $\mathrm{Al}_{2} \mathrm{O}_{3}$ (AR, Sinopharm Chemical Reagent Beijing Co., Ltd.) and $7.25 \mathrm{~g}$ formamide (AR, Sinopharm Chemical Reagent Beijing Co., Ltd.) were added. The reacting solution was transferred to $200 \mathrm{~mL}$ Teflon-lined stainless autoclave and heated to $120^{\circ} \mathrm{C}$ for $12 \mathrm{~h}$. After cooled down to room temperature, the product was collected by centrifugation and washed with distilled water and absolute ethanol (AR, Sinopharm Chemical Reagent Beijing Co., Ltd.) 4 times, and then dried at $80{ }^{\circ} \mathrm{C}$ for several hours. The obtained solid was sintered at $900{ }^{\circ} \mathrm{C}$ for $2 \mathrm{~h}$. Finally, the as- synthesized $\mathrm{Fe}_{2} \mathrm{O}_{3}[104] / \mathrm{Al}_{2} \mathrm{O}_{3}$ $(60 \%$, mass fraction) samples were further ground and sieved to 63-106 $\mu \mathrm{m}$ for use.

The referenced $\mathrm{Fe}_{2} \mathrm{O}_{3} / \mathrm{Al}_{2} \mathrm{O}_{3}$ was prepared following the traditional precipitation method. ${ }^{34}$ The morphological characterizations of the prepared and the regenerated OCs were performed by LEO1450 scanning electron microscope (SEM, LEO, USA), H9000NAR high-resolution transmission electron microscopy (HRTEM, Hitachi, Japan), D/MAX-RB X-ray diffraction (XRD, Rigaku, Japan), and Autosorb-iQ-MP Brunauer-Emmett-Teller (BET, Quantachrome, USA).

The reaction between the synthesized OCs and $\mathrm{CO}$ was conducted in a simultaneous thermal analyzer (TGq500) under $\mathrm{N}_{2}$ at $900{ }^{\circ} \mathrm{C}$. The flow rate of $\mathrm{N}_{2}$ is $100 \mathrm{~mL} \cdot \mathrm{min}^{-1}$. As comparison, reaction between $\mathrm{CO}$ and the referenced $\mathrm{Fe}_{2} \mathrm{O}_{3} / \mathrm{Al}_{2} \mathrm{O}_{3}$ was also performed under the same conditions. Reactivity data as a function of time were obtained from the mass variations during the reduction-oxidation cycles. The degree of solid conversion $\chi$ is defined as follow:

$$
\chi=\frac{m_{\mathrm{ox}}-m}{m_{\mathrm{ox}}-m_{\mathrm{red}}} \times 100 \%
$$

where $m$ is the actual mass of sample, $m_{\mathrm{ox}}$ is the mass of the sample when it was fully oxidized; $m_{\text {red }}$ is the mass of the sample in the fully reduced form.

\subsection{Computational model and methods}

All density functional theory calculations were performed by the CASTEP $^{35}$ with the generalized gradient approximation $(\mathrm{GGA})^{36}$ for describing electron- electron interactions, since GGA can predict the ground state of bulk iron more accurately than local density approximation (LDA) or local spin density approximation (LSDA) ${ }^{37}$ Hubbard parameter ( $\left.U_{\text {eff }}\right)$ was set to be $4.5 \mathrm{eV}$ in our calculation, which provides the best match to the experimental 

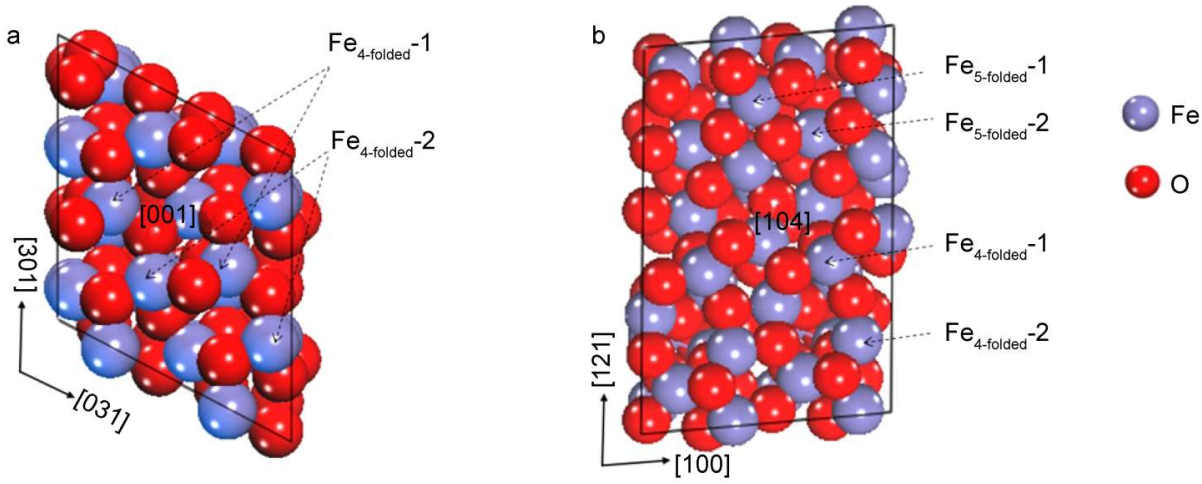

Fig.2 3-layer model and site terminology of the stoichiometric (a) $\mathrm{Fe}_{2} \mathrm{O}_{3}[001] 2 \times 2$ super-cell surface and (b) $\mathrm{Fe}_{2} \mathrm{O}_{3}[104] 1 \times 2$ super-cell surface

band gaps of hematite. ${ }^{38}$ The magnetic configuration $(+--+)$ was set for $\mathrm{Fe}$ atoms in the rhombohedral unit cell of $\mathrm{Fe}_{2} \mathrm{O}_{3}$, which makes the optimized cell at the lowest total energy, ${ }^{39-42}+$ and designated up- and down-spin directions with respect to the $z$-axis. The interaction between the valence electrons and the ionic core was described by the Perdew, Burke, and Ernzerhof (PBE) gradient-corrected functional and the effective core potential (ECP). ${ }^{43}$ Valence electron wave functions were expanded by double numeric with polarization (DNP). The kinetic energy cutoff $\left(E_{\text {cut }}\right)$ was $350 \mathrm{eV}$; the Monkhorst-Pack $k$-mesh was $4 \times 4 \times 1$. Calculation used an energy convergence tolerance of $1 \times 10^{-4} \mathrm{eV}$ and a gradient convergence of $5 \times 10^{-1} \mathrm{eV} \cdot \mathrm{nm}^{-1}$. The formulation of the linear synchronous transit (LST) and quadratic synchronous transit (QST) methods were used to search the transition states for each reaction. ${ }^{44}$

$\mathrm{Fe}_{2} \mathrm{O}_{3}[104] 2 \times 1$ super-cell surface and $\mathrm{Fe}_{2} \mathrm{O}_{3}[001] 2 \times 2$ supercell surface slabs were cleaved from the optimized $\alpha-\mathrm{Fe}_{2} \mathrm{O}_{3}$ bulk structure, as shown in Fig.2. The stoichiometric [001] surface exhibits two nonequivalent $\mathrm{Fe}$ sites $\left(\mathrm{Fe}_{4 \text {-folded }}-1\right.$ and $\left.\mathrm{Fe}_{4 \text {-folded }}-2\right)$ that bond to three $\mathrm{O}$ atoms on the top layer and one $\mathrm{O}$ atom on the second layer. The stoichiometric [104] surface exhibits four different $\mathrm{Fe}$ sites, including two nonequivalent $\mathrm{Fe}_{5 \text {-folded }}-1$ and $\mathrm{Fe}_{5 \text {-folded }}{ }^{-}$ 2 that bond to four $\mathrm{O}$ atoms on the top layer and one $\mathrm{O}$ atom on

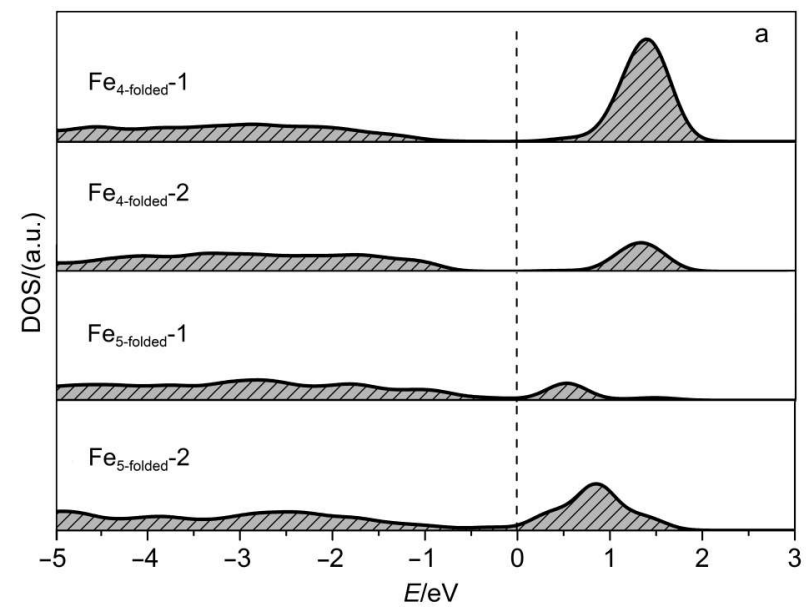

the second layer, respectively, $\mathrm{Fe}_{4 \text { - folded }} 1$ that bonds to three $\mathrm{O}$ atoms on the top layer and one $\mathrm{O}$ atom on the second layer, and $\mathrm{Fe}_{\text {4-folded }} 2$ that bonds to four $\mathrm{O}$ atoms on the top layer. All the $\mathrm{Fe}$ atoms on [001] surface or [104] surface are unsaturated, since the coordination number of bulk Fe is six. Geometry optimization was performed using DFT calculations and the optimized structure was obtained after fully relaxation by minimizing total energy. Then the electronic properties, reaction behavior, and oxygen transfer were detected.

\section{Results and discussion}

\subsection{Electronic property}

$\mathrm{C}$ atom of $\mathrm{CO}$ prefers to binding to the metal site of oxide mainly due to $\sigma$ donation from $3 p_{z}$ of $\mathrm{CO}$ and $3 d_{z^{2}}$ of metal oxide surface. ${ }^{45}$ Therefore, we compared the partial density of states (PDOS) for these $\mathrm{Fe}$ atoms of $\mathrm{Fe}_{2} \mathrm{O}_{3}[104]$ and $\mathrm{Fe}_{2} \mathrm{O}_{3}[001]$, as shown in Fig.3. For $\mathrm{Fe}_{2} \mathrm{O}_{3}$ [104], the DOS curves show that the $3 d$ electrons of $\mathrm{Fe}$ atoms on the top layer delocalizes below and near the Fermi level $\left(E_{\mathrm{f}}=0.0 \mathrm{eV}\right)$. The highest occupation molecular orbital (HOMO) of $\mathrm{Fe}_{\text {-folded }}-1$ is at higher energy level than those of $\mathrm{Fe}_{\text {-folded }}-2, \mathrm{Fe}_{4 \text {-folded }}-1$, and $\mathrm{Fe}_{4 \text {-folded }}-2$, while the lowest unoccupied molecular orbital (LUMO) of $\mathrm{Fe}_{\text {s-folded }}-1$ appears at lower energy level than those of $\mathrm{Fe}_{5 \text {-folded }}-2, \mathrm{Fe}_{4 \text {-folded }}-1$, and $\mathrm{Fe}_{4 \text {-folded }}-2$ above the

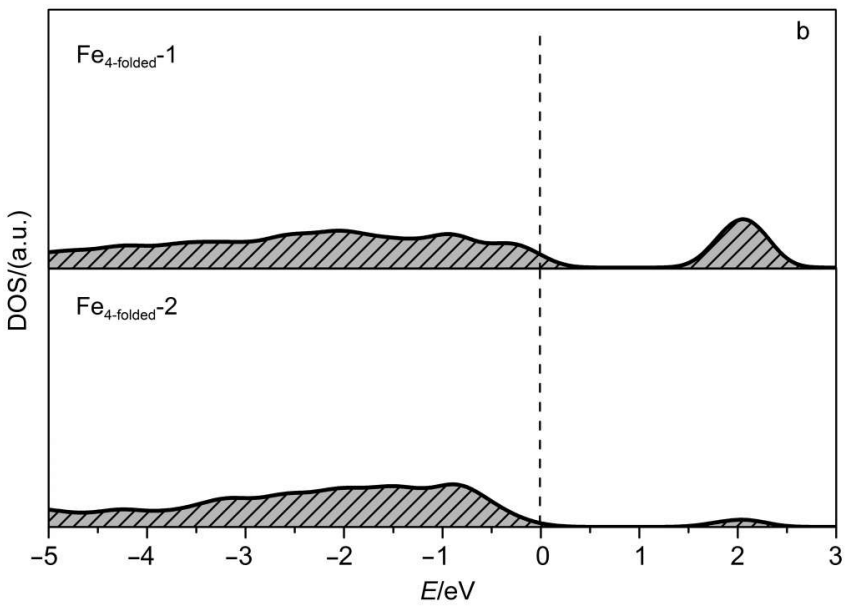

Fig.3 $3 d_{\mathrm{Fe}}-\mathrm{DOS}$ of (a) $\mathrm{Fe}_{2} \mathrm{O}_{3}[104]$ and (b) $\mathrm{Fe}_{2} \mathrm{O}_{3}[001]$ 
Fermi level $(0.0 \mathrm{eV})$. Therefore, the energy gap $\left(E_{\text {gap }}\right)$ between HOMO and LUMO for $\mathrm{Fe}_{\text {s-folded }} 1$ is the smallest $(\sim 1.0 \mathrm{eV})$, while $E_{\text {gap }}$ for $\mathrm{Fe}_{\text {s-folded }}-2$ is $\sim 1.5 \mathrm{eV}$, and $E_{\text {gap }}$ for $\mathrm{Fe}_{4 \text {-folded }}-1$ and $\mathrm{Fe}_{4 \text {-folded }}-2$ is about $2.0 \mathrm{eV}$.

The calculated $E_{\text {gap }}$ of $\mathrm{Fe}_{4 \text {-folded }}-1$ and $\mathrm{Fe}_{4 \text {-folded }}-2$ of $\mathrm{Fe}_{2} \mathrm{O}_{3}[001]$ are about $2.0 \mathrm{eV}$, close to the results of $2.0-2.1 \mathrm{eV}^{46,47}$ which is larger than that of $\mathrm{Fe}_{\text {s-folded }}-1$ on $\mathrm{Fe}_{2} \mathrm{O}_{3}$ [104]. The small $E_{\text {gap }}$ for the $\mathrm{Fe}_{\text {s-folded }}{ }^{-}$ 1 atom of $\mathrm{Fe}_{2} \mathrm{O}_{3}$ [104] will benefit the acceptance of electron. We adopt LUMO energies of $\mathrm{Fe}_{2} \mathrm{O}_{3}[104]$ and $\mathrm{Fe}_{2} \mathrm{O}_{3}$ [001] to characterize their Lewis acidity and the HOMO energy of CO to characterize their Lewis basicity, respectively. The energy gap between the two orbitals can be used to predict how $\mathrm{CO}$ interacts with $\mathrm{Fe}_{2} \mathrm{O}_{3}$, which can be calculated using the equation below:

$E_{\text {LUмо-номо }}=E_{\text {LUмо }}\left(\mathrm{Fe}_{2} \mathrm{O}_{3}\right)-E_{\text {номо }}(\mathrm{CO})$

where $E_{\text {Luмо }}\left(\mathrm{Fe}_{2} \mathrm{O}_{3}\right)$ and $E_{\text {номо }}(\mathrm{CO})$ are the LUMO energy of $\mathrm{Fe}_{2} \mathrm{O}_{3}$ and the $\mathrm{HOMO}$ energy of $\mathrm{CO}$, respectively. The $E_{\text {Lимо-номо }}$ of the $\mathrm{CO}-\mathrm{Fe}_{2} \mathrm{O}_{3}[104]$ system is $-3.82 \mathrm{eV}$, while the $E_{\text {Luмо-номо }}$ of the $\mathrm{CO}$ $\mathrm{Fe}_{2} \mathrm{O}_{3}[001]$ system is $-4.91 \mathrm{eV}$. The $E_{\text {Luмо-номо implies that } \mathrm{Fe}_{2} \mathrm{O}_{3}}$ [104] will be more active than $\mathrm{Fe}_{2} \mathrm{O}_{3}[001]$ for initiating CLC reaction of CO.

\subsection{Reaction activity of surface}

$\mathrm{CO}$ was approached to the active site $\mathrm{Fe}_{5 \text {-folded }}-1$ of $\mathrm{Fe}_{2} \mathrm{O}_{3}[104]$ and $\mathrm{Fe}_{4 \text {-folded }}-1$ of $\mathrm{Fe}_{2} \mathrm{O}_{3}[001]$ to do optimization. Results show that $\mathrm{CO}$ binds to $\mathrm{Fe}_{\text {s-folded }}-1$ and $\mathrm{Fe}_{4 \text {-folded }}-1$, respectively. For the stable configuration of $\mathrm{CO}-\mathrm{Fe}_{2} \mathrm{O}_{3}[104]$, the tilt angle is $171^{\circ} 414^{\prime}$, the bond length of the adsorbed $\mathrm{CO}$ is $0.115 \mathrm{~nm}$, the distance between $\mathrm{CO}$ and $\mathrm{Fe}_{\text {s-folded }}-1$ is $0.180 \mathrm{~nm}$. For the stable configuration of $\mathrm{CO}-$ $\mathrm{Fe}_{2} \mathrm{O}_{3}[001]$, the tilt angle is $171^{\circ} 414^{\prime}$, the bond length of the adsorbed $\mathrm{CO}$ is $0.116 \mathrm{~nm}$, the distance between $\mathrm{CO}$ and $\mathrm{Fe}_{4 \text {-folded }}-1$ is $0.186 \mathrm{~nm}$. Hybrid occurred between $\mathrm{C}$ and $\mathrm{Fe}$ for both the CO$\mathrm{Fe}_{2} \mathrm{O}_{3}[104]$ interaction system and the $\mathrm{CO}-\mathrm{Fe}_{2} \mathrm{O}_{3}[001]$ interaction system. The hybrid weakened the $\mathrm{CO}$ bond, resulting in a red shift of the $\mathrm{C}-\mathrm{O}$ bond of the adsorbed $\mathrm{CO}$ to lower wavenumbers with respect to that of the gas-phase $\mathrm{CO}$.

The binding energy for $\mathrm{CO}$ on $\mathrm{Fe}_{2} \mathrm{O}_{3}$ [104] and $\mathrm{Fe}_{2} \mathrm{O}_{3}$ [001], $E_{\text {bind-co, }}$ was calculated respectively using the following expression as mentioned in previous works: $:^{48,49}$

$$
E_{\text {bind-CO }}=E(\mathrm{CO}-\mathrm{OC})-E(\mathrm{OC})-E(\mathrm{CO})
$$

where $E(\mathrm{CO}-\mathrm{OC})$ and $E(\mathrm{OC})$ are the total energies of the $\mathrm{Fe}_{2} \mathrm{O}_{3}$ [104] or $\mathrm{Fe}_{2} \mathrm{O}_{3}[001]$ with and without the presence of CO molecule, respectively, and $E(\mathrm{CO})$ is the total energy of an isolated $\mathrm{CO}$ molecule. The interaction between $\mathrm{CO}$ and $\mathrm{Fe}_{2} \mathrm{O}_{3}[104]$, in terms of binding energies, is $-0.221 \mathrm{eV}$, while $E_{\text {bind-co }}$ for the interaction between $\mathrm{CO}$ and $\mathrm{Fe}_{2} \mathrm{O}_{3}[001]$ is $-0.786 \mathrm{eV}$. Both the absorption of $\mathrm{CO}$ on $\mathrm{Fe}_{2} \mathrm{O}_{3}[104]$ and the absorption of $\mathrm{CO}$ on $\mathrm{Fe}_{2} \mathrm{O}_{3}[001]$ are exothermic processes. The less heat release from the absorption process of $\mathrm{CO}$ on $\mathrm{Fe}_{2} \mathrm{O}_{3}[104]$ will lead to better adsorption of $\mathrm{CO}$ on the surface at high temperature during CLC, while compared to the $\mathrm{CO}-\mathrm{Fe}_{2} \mathrm{O}_{3}[001]$ case.

Then we discussed the oxidation of $\mathrm{CO}$ into $\mathrm{CO}_{2}$ by the surface lattice oxygen (1), (2), (3), and (4)) bonded to $\mathrm{Fe}_{5 \text {-folded }}-1$ on $\mathrm{Fe}_{2} \mathrm{O}_{3}$ [104], and by the surface lattice oxygen atom (1), (2), and (3)) bonded to $\mathrm{Fe}_{4 \text {-folded }}-1$ on $\mathrm{Fe}_{2} \mathrm{O}_{3}[001]$, respectively. The reaction initiates from the stable adsorption configurations of $\mathrm{CO}$ on $\mathrm{Fe}_{5 \text {-folded }}-1$ of $\mathrm{Fe}_{2} \mathrm{O}_{3}$ [104] and $\mathrm{CO}$ on $\mathrm{Fe}_{4 \text {-folded }}-1$ of $\mathrm{Fe}_{2} \mathrm{O}_{3}$ [001]. Fig.4 shows the calculated potential energy profiles for the most accessible channels of $\mathrm{CO}$ oxidation into $\mathrm{CO}_{2}$ on $\mathrm{Fe}_{5 \text {-folded }}-1$ of $\mathrm{Fe}_{2} \mathrm{O}_{3}$ [104] and on $\mathrm{Fe}_{4 \text {-folded }}-1$ of $\mathrm{Fe}_{2} \mathrm{O}_{3}$ [001]. A qualitatively similar twostep reaction mechanism for the reaction between $\mathrm{CO}$ and $\mathrm{Fe}_{2} \mathrm{O}_{3}$ [104] $\left\{\right.$ and $\left.\mathrm{Fe}_{2} \mathrm{O}_{3}[001]\right\}$ was obtained. The first step relates to the conversion from the initial state (IS) to a carbonate species at the intermediate state (MS). The second reaction step initiated from the MS and changed into the final state (FS) with the release of $\mathrm{CO}_{2}$ from the surface. The total activation energy $\left(E_{\mathrm{a}}\right)$ and reaction enthalpy $\left(E_{\mathrm{r}}\right)$ for $\mathrm{CO}+\mathrm{Fe}_{2} \mathrm{O}_{3}[104] \rightarrow \mathrm{CO}_{2}+\mathrm{Fe}_{2} \mathrm{O}_{3}[104]_{\text {red }}$ (reduced $\left.\mathrm{Fe}_{2} \mathrm{O}_{3}[104]\right)$ are 0.681 and $-0.776 \mathrm{eV}$, respectively, while $E_{\text {a }}$ and $E_{\mathrm{r}}$ for $\mathrm{CO}+\mathrm{Fe}_{2} \mathrm{O}_{3}[001] \rightarrow \mathrm{CO}_{2}+\mathrm{Fe}_{2} \mathrm{O}_{3}[001]_{\text {red }}$ (reduced $\mathrm{Fe}_{2} \mathrm{O}_{3}[001]$ ) are 1.203 and $-0.392 \mathrm{eV}$, respectively. The latter $E_{\mathrm{a}}$ is almost twice as high as the former, which suggests that the oxidation of $\mathrm{CO}$ by $\mathrm{Fe}_{2} \mathrm{O}_{3}[104]$ is more accessible than by $\mathrm{Fe}_{2} \mathrm{O}_{3}$ [001]. The reaction $\mathrm{CO}+\mathrm{Fe}_{2} \mathrm{O}_{3}[104] \rightarrow \mathrm{CO}_{2}+\mathrm{Fe}_{2} \mathrm{O}_{3}[104]_{\text {red }}$ releases more energy than $\mathrm{CO}+\mathrm{Fe}_{2} \mathrm{O}_{3}[001] \rightarrow \mathrm{CO}_{2}+\mathrm{Fe}_{2} \mathrm{O}_{3}[001]_{\text {red. }}$. Results show that $\mathrm{Fe}_{2} \mathrm{O}_{3}$ [104] surface is more chemically active than $\mathrm{Fe}_{2} \mathrm{O}_{3}[001]$ surface for oxidizing $\mathrm{CO}$ during CLC.

\subsection{Regeneration behavior}

During CLC processes, after the $\mathrm{CO}$ was oxidized by $\mathrm{Fe}_{2} \mathrm{O}_{3}$ [104] and $\mathrm{Fe}_{2} \mathrm{O}_{3}$ [001], $\mathrm{Fe}_{2} \mathrm{O}_{3}$ [104] and $\mathrm{Fe}_{2} \mathrm{O}_{3}$ [001] were reduced; then the reduced $\mathrm{Fe}_{2} \mathrm{O}_{3}[104]_{\text {red }}$ and $\mathrm{Fe}_{2} \mathrm{O}_{3}[001]_{\text {red }}$ would be transferred to the air reactor, where $\mathrm{Fe}_{2} \mathrm{O}_{3}[104]_{\mathrm{red}}$ and $\mathrm{Fe}_{2} \mathrm{O}_{3}[001]_{\text {red }}$ would be oxidized by $\mathrm{O}_{2}$ into $\mathrm{Fe}_{2} \mathrm{O}_{3}[104]$ and $\mathrm{Fe}_{2} \mathrm{O}_{3}[001]$. Therefore, the regeneration reaction was initiated from the adsorption of $\mathrm{O}_{2}$ on $\mathrm{Fe}_{2} \mathrm{O}_{3}[104]_{\text {red }}$ and $\mathrm{Fe}_{2} \mathrm{O}_{3}[001]_{\text {red, }}$, which were then oxidized by the adsorbed $\mathrm{O}_{2}$. Actually, only one $\mathrm{O}$ atom is needed for oxidizing $\mathrm{Fe}_{2} \mathrm{O}_{3}[104]_{\text {red }}$ or $\mathrm{Fe}_{2} \mathrm{O}_{3}[001]_{\text {red }}$ into $\mathrm{Fe}_{2} \mathrm{O}_{3}[104]$ or $\mathrm{Fe}_{2} \mathrm{O}_{3}$ [001]. We pushed one $\mathrm{O}$ of $\mathrm{O}_{2}$ to the defected site of $\mathrm{Fe}_{2} \mathrm{O}_{3}[104]_{\text {red }}$ or $\left[\mathrm{Fe}_{2} \mathrm{O}_{3}[001]_{\mathrm{red}}\right.$ to do geometrical optimization to define the final reaction state. At the stable final configuration of the $\mathrm{O}_{2}-\mathrm{Fe}_{2} \mathrm{O}_{3}$ $[104]_{\mathrm{red}}$ system, one $\mathrm{O}$ atom from $\mathrm{O}_{2}$ fixes into the defected site of $\mathrm{Fe}_{2} \mathrm{O}_{3}[104]_{\text {red }}$ very well in an one-step oxidation reaction mecha-

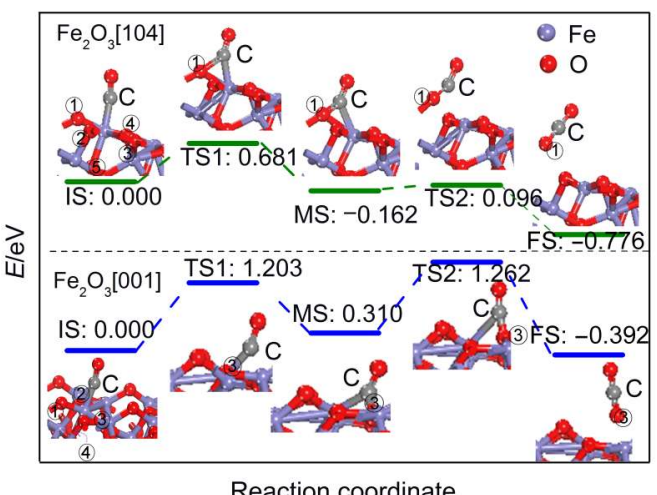

Fig.4 Calculated potential energy profiles for $\mathrm{CO}$ oxidation on $\mathrm{Fe}_{5 \text {-folded }}-1$ of $\mathrm{Fe}_{2} \mathrm{O}_{3}[104]$ and on $\mathrm{Fe}_{4 \text {-folded }}-1$ of $\mathrm{Fe}_{2} \mathrm{O}_{3}[001]$ The IS, TS, MS, and FS denote the initial state, transition state, intermediate species, and final state, respectively. The data are the energies for the crucial points referenced to the initial state set at $0.000 \mathrm{eV}$. 

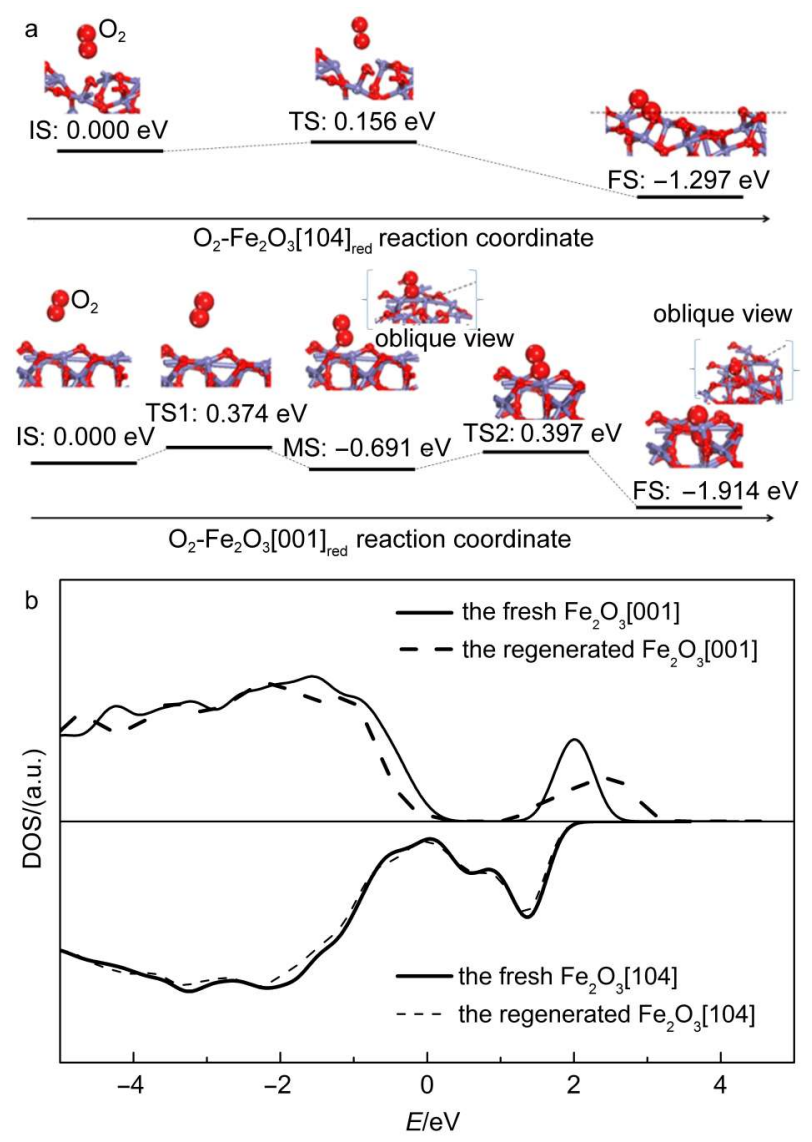

Fig.5 (a) Potential energy profiles for the oxidation of $\mathrm{Fe}_{2} \mathrm{O}_{3}[104]_{\text {red }}$ and $\mathrm{Fe}_{2} \mathrm{O}_{3}[001]_{\text {red }}$ by $\mathrm{O}_{2}$, and (b) comparison of DOS for the fresh and the regenerated $\mathrm{OC}$

nism, as shown in the upper reaction path in Fig.5a. However, the oxidation reaction of $\mathrm{Fe}_{2} \mathrm{O}_{3}[001]_{\text {red }}$ crossed the barrier of $0.374 \mathrm{eV}$ at the MS which subsequently overcome a barrier of $0.397 \mathrm{eV}$ into the final state (FS), as shown in the lower reaction path in Fig.5a. At the final state of $\mathrm{O}_{2}-\mathrm{Fe}_{2} \mathrm{O}_{3}[001]_{\text {red }}$, one $\mathrm{O}$ atom of $\mathrm{O}_{2}$ embedded into the surface of $\mathrm{Fe}_{2} \mathrm{O}_{3}[001]_{\text {red }}$ and the other excess $\mathrm{O}$ atom is adsorbed on the top layer. Both the oxidation of $\mathrm{Fe}_{2} \mathrm{O}_{3}[104]_{\text {red }}$ and the oxidation of $\mathrm{Fe}_{2} \mathrm{O}_{3}[001]_{\text {red }}$ by $\mathrm{O}_{2}$ are energetically accessible.

However, surface reconstructions help in understanding surface chemistry of oxygen carriers, especially in the case where the surfaces can be structurally regenerated. Table 1 lists the average relaxation of $\mathrm{Fe}$ and $\mathrm{O}$ atoms on the regenerated surfaces in the direction vertically to the slab models. The average relaxations of $\mathrm{Fe}$ and $\mathrm{O}$ atoms on $\mathrm{Fe}_{2} \mathrm{O}_{3}[104]_{\text {red }}$ are smaller than those on $\mathrm{Fe}_{2} \mathrm{O}_{3}$ $[001]_{\text {red. }}$ But, in general, both $\mathrm{Fe}_{2} \mathrm{O}_{3}[104]_{\text {red }}$ and $\mathrm{Fe}_{2} \mathrm{O}_{3}[001]_{\text {red }}$ underwent slight surface atom relaxation after regeneration. The change of electronic state will therefore occur with the atom re-

Table 1 Average relaxation of $\mathrm{Fe}$ and $\mathrm{O}$ atoms on the regenerated surfaces in the direction vertically to the slab models

\begin{tabular}{ccc}
\hline & $\mathrm{Fe}$ atom & $\mathrm{O}$ atom \\
\hline $\mathrm{Fe}_{2} \mathrm{O}_{3}[104]_{\mathrm{red}}$ & $0.2 \%$ & $1.2 \%$ \\
$\mathrm{Fe}_{2} \mathrm{O}_{3}[001]_{\mathrm{red}}$ & $2.1 \%$ & $2.9 \%$ \\
\hline
\end{tabular}

laxation, as the DOS shown in Fig.5b. Except for little change happened to the DOS before and after regeneration, the DOS of the regenerated surface, especially the regenerated $\mathrm{Fe}_{2} \mathrm{O}_{3}[104]$, matches that of the fresh surface very well. Results of the oxidation reactions energetically and structurally verified that the possibility of regeneration of the reduced $\mathrm{Fe}_{2} \mathrm{O}_{3}[104]$.

\subsection{Oxygen transfer}

Oxygen carrying capacity and transfer in the OC system plays an important role in CLC. We examined the oxygen transfer on the surfaces of $\mathrm{Fe}_{2} \mathrm{O}_{3}[104]$ and $\mathrm{Fe}_{2} \mathrm{O}_{3}[001]$ by gradually removing the top layer $\mathrm{O}$ atoms to form non-stoichiometric surfaces during the further reductions of $\mathrm{Fe}_{2} \mathrm{O}_{3}[104]$ and $\mathrm{Fe}_{2} \mathrm{O}_{3}$ [001], results of which are listed in Fig.6. In Fig.6a, after the top layer $\mathrm{O}$ atoms of $\mathrm{Fe}_{22} \mathrm{O}_{33}, \mathrm{Fe}_{22} \mathrm{O}_{29}, \mathrm{Fe}_{22} \mathrm{O}_{22}$, and $\mathrm{Fe}_{22} \mathrm{O}_{15}$ are removed, oxygen atoms of the inner layers transfer to the top layer. Then, $\mathrm{Fe}$ atom dominates the top layer after $\mathrm{Fe}_{22} \mathrm{O}_{15}$. In Fig.6b, the optimized $\mathrm{Fe}_{32} \mathrm{O}_{48}$, $\mathrm{Fe}_{32} \mathrm{O}_{44}$, and $\mathrm{Fe}_{32} \mathrm{O}_{36}$ show relatively high $\mathrm{O}$ atom coverage; then the surface of the optimized $\mathrm{Fe}_{32} \mathrm{O}_{26}$ is almost completely covered by $\mathrm{Fe}$ atoms except for only one $\mathrm{O}$ atom. Fe atoms hinder further oxidation of $\mathrm{CO}$ into $\mathrm{CO}_{2}$. Instead, hybrid between $\mathrm{CO}$ and $\mathrm{Fe}$ would promote $\mathrm{Fe}$-catalyzed carbon deposit reaction $(2 \mathrm{CO} \stackrel{\mathrm{Fe}}{\rightarrow} \mathrm{C}+$ $\left.\mathrm{CO}_{2}\right){ }^{48}$ rather than $\mathrm{CO}$ oxidation reaction. In comparison with the low oxygen transfer on $\mathrm{Fe}_{2} \mathrm{O}_{3}[001]$, the higher oxygen transfer capacity of $\mathrm{Fe}_{2} \mathrm{O}_{3}[104]$ would result in more complete reduction of $\mathrm{Fe}_{2} \mathrm{O}_{3}$ [104].

\subsection{Deep reduction}

To further investigate the deep reduction of $\mathrm{Fe}_{2} \mathrm{O}_{3}[104]$ and $\mathrm{Fe}_{2} \mathrm{O}_{3}[001]$, we initiated the reactions from the stable physisorption of $\mathrm{CO}$ on the top layers of $\mathrm{Fe}_{22} \mathrm{O}_{33}, \mathrm{Fe}_{22} \mathrm{O}_{29}, \mathrm{Fe}_{22} \mathrm{O}_{20}$, $\mathrm{Fe}_{22} \mathrm{O}_{15}, \mathrm{Fe}_{22} \mathrm{O}_{10}, \mathrm{Fe}_{32} \mathrm{O}_{48}, \mathrm{Fe}_{32} \mathrm{O}_{44}, \mathrm{Fe}_{32} \mathrm{O}_{36}$, and $\mathrm{Fe}_{32} \mathrm{O}_{26}$, respectively. The energy profiles for the most possible redox reaction (with the lowest $E_{\mathrm{a}}$ ) on these surfaces are illustrated in Fig.7, respectively, where $y$-ordinate is the energy in $\mathrm{eV}$ and the $x$-ordinate is the gradual reduction reaction coordinate for $\mathrm{Fe}_{2} \mathrm{O}_{3}[104]$ and $\mathrm{Fe}_{2} \mathrm{O}_{3}$ [001] by CO. Reduction of $\mathrm{Fe}_{22} \mathrm{O}_{33}, \mathrm{Fe}_{22} \mathrm{O}_{29}, \mathrm{Fe}_{22} \mathrm{O}_{20}, \mathrm{Fe}_{22} \mathrm{O}_{15}$, and $\mathrm{Fe}_{22} \mathrm{O}_{10}$ by $\mathrm{CO}$ followed a two-step reaction mechanism, where the first step led to the generation of carbonate species on the surfaces while the second step was for the desorption of the carbonate species that changed into a free $\mathrm{CO}_{2}$, which is similar to our previous discovery on $\mathrm{Fe}_{2} \mathrm{O}_{3}[1 \overline{1} 2]^{49}$ and $\mathrm{Fe}_{2} \mathrm{O}_{3}$ cluster ${ }^{34}$. $E_{\text {a }}$ for every reaction step on $\mathrm{Fe}_{22} \mathrm{O}_{33}, \mathrm{Fe}_{22} \mathrm{O}_{29}, \mathrm{Fe}_{22} \mathrm{O}_{20}, \mathrm{Fe}_{22} \mathrm{O}_{15}$, and $\mathrm{Fe}_{22} \mathrm{O}_{10}$ is below $2 \mathrm{eV}$. Results show that $E_{\text {a }}$ increases slightly with the decrease of the valence states $\left(Q_{v}\right)$ of $\mathrm{Fe}$ atoms of $\mathrm{Fe}_{22} \mathrm{O}_{33}, \mathrm{Fe}_{22} \mathrm{O}_{29}$, $\mathrm{Fe}_{22} \mathrm{O}_{20}, \mathrm{Fe}_{22} \mathrm{O}_{15}$, and $\mathrm{Fe}_{22} \mathrm{O}_{10}$.

The reduction of $\mathrm{Fe}_{32} \mathrm{O}_{48}, \mathrm{Fe}_{32} \mathrm{O}_{44}$, and $\mathrm{Fe}_{32} \mathrm{O}_{36}$ by $\mathrm{CO}$ followed a two-step reaction mechanism, while the reduction of $\mathrm{Fe}_{32} \mathrm{O}_{26}$ followed a one-step reaction mechanism. $E_{\text {a }}$ for the reduction of $\mathrm{Fe}_{32} \mathrm{O}_{48}$ and $\mathrm{Fe}_{32} \mathrm{O}_{40}$ is below $2 \mathrm{eV}$, respectively, while $E_{\text {a }}$ for the reduction of $\mathrm{Fe}_{32} \mathrm{O}_{44}$ and $\mathrm{Fe}_{32} \mathrm{O}_{36}$ is a bit higher than $2 \mathrm{eV}$. However, the reaction between $\mathrm{CO}$ and $\mathrm{Fe}_{32} \mathrm{O}_{26}$ crossed rather high barrier $\left(E_{\mathrm{a}}>14 \mathrm{eV}\right)$. The high $E_{\mathrm{a}}$ together with the limited oxygen carrying capacity decides the lower reaction activity and reduction degree of $\mathrm{Fe}_{2} \mathrm{O}_{3}$ [001], in comparison with $\mathrm{Fe}_{2} \mathrm{O}_{3}[104]$. If completely 

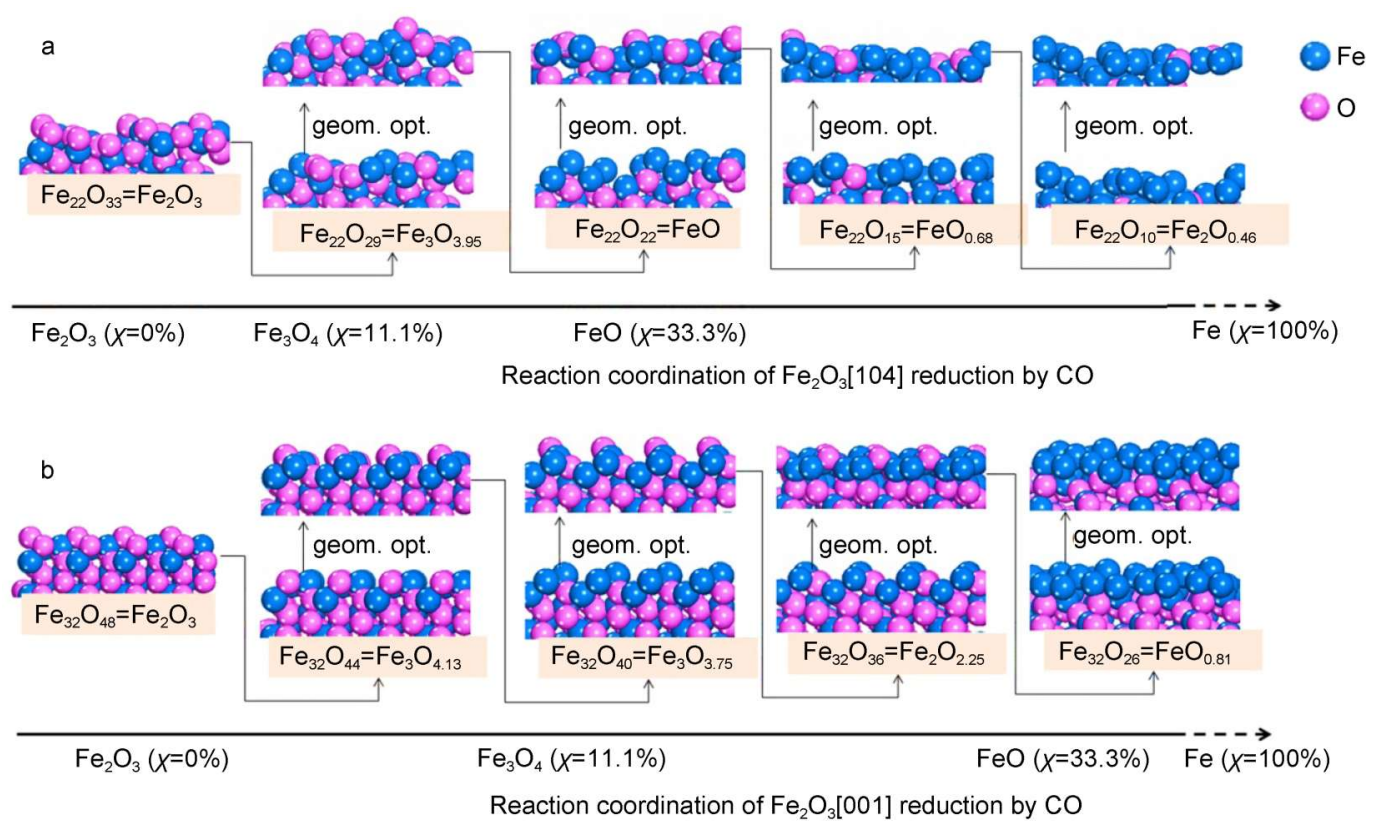

Fig.6 Oxygen transfer on (a) $\mathrm{Fe}_{2} \mathrm{O}_{3}[104]$ and (b) $\mathrm{Fe}_{2} \mathrm{O}_{3}[001]$ geom. opt.: geometry optimization

covered by the [001] facet, the reduction of the single crystal ironbased oxygen carrier should be very limited. However, it is known that different facets (including low and high index facets) expose on the iron-based oxygen carrier used for the chemical looping combustion in previous research works, ${ }^{14,34}$ where the high index facet could benefit the deep reduction of $\mathrm{Fe}_{2} \mathrm{O}_{3}$ into Fe. Obviously, surface morphology greatly decides the reaction performance of iron-based OC during CLC.

\subsection{Experimental control}

Fig.8a shows the CLC reactions between $\mathrm{CO}$ and $\mathrm{Fe}_{2} \mathrm{O}_{3}[104] /$
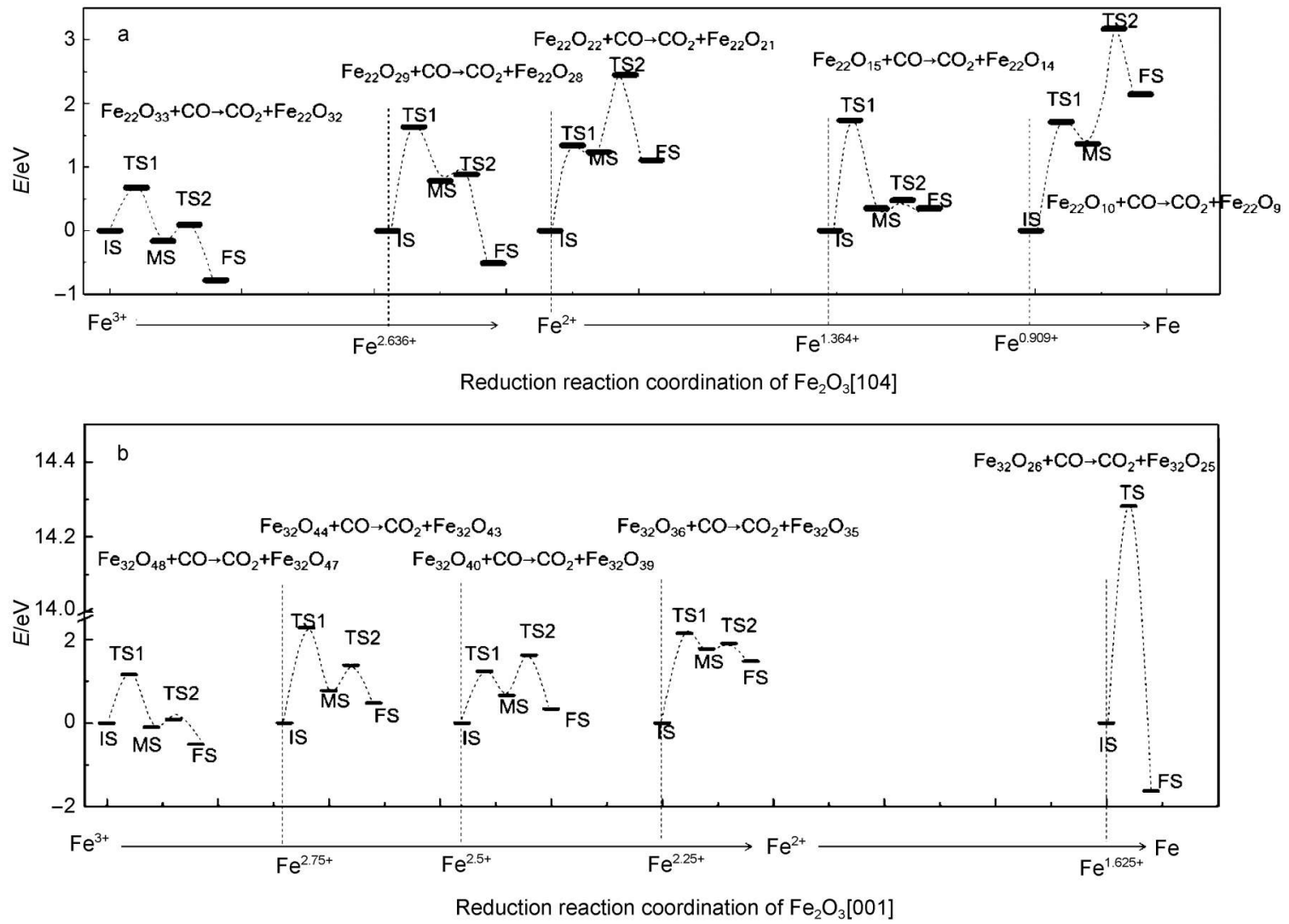

Fig.7 Energy profile for oxidation of $\mathrm{CO}$ using (a) $\mathrm{Fe}_{2} \mathrm{O}_{3}[104]$ and (b) $\mathrm{Fe}_{2} \mathrm{O}_{3}[001]$ 

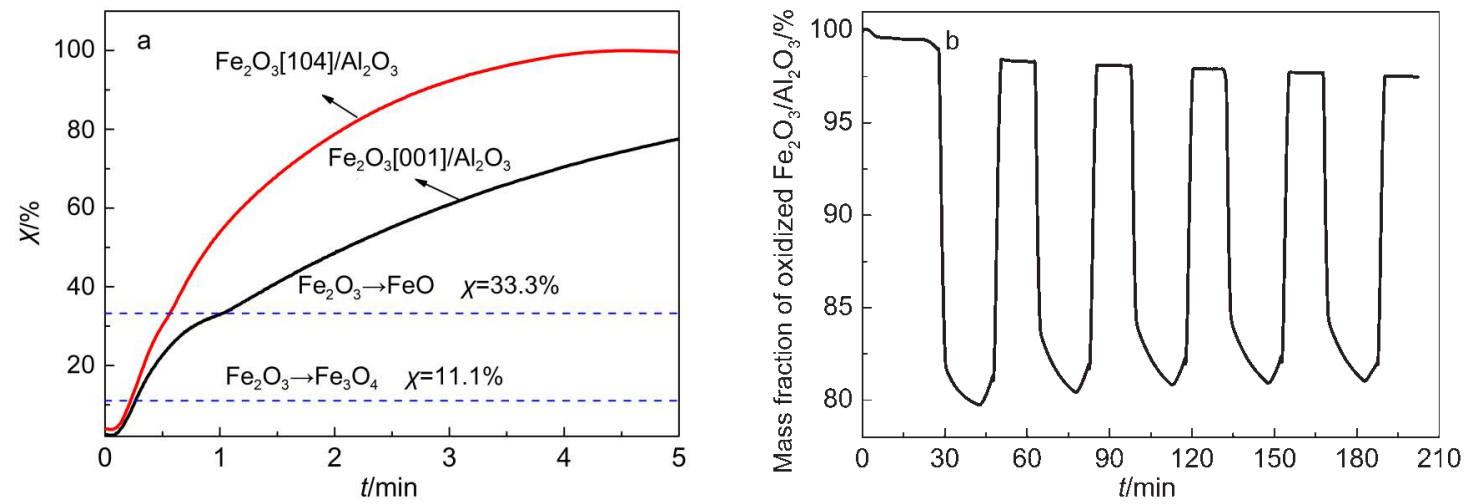

Fig.8 (a) Conversion $(\chi)$ as a function of reaction time for the reaction between $\mathrm{CO}$ and $\mathrm{Fe}_{2} \mathrm{O}_{3}[104] / \mathrm{Al}_{2} \mathrm{O}_{3}$, and the referenced reaction between $\mathrm{CO}$ and $\mathrm{Fe}_{2} \mathrm{O}_{3} / \mathrm{Al}_{2} \mathrm{O}_{3}$, at $900{ }^{\circ} \mathrm{C}$; (b) re-use of $\mathrm{Fe}_{2} \mathrm{O}_{3}[104] / \mathrm{Al}_{2} \mathrm{O}_{3}$ at $900{ }^{\circ} \mathrm{C}$
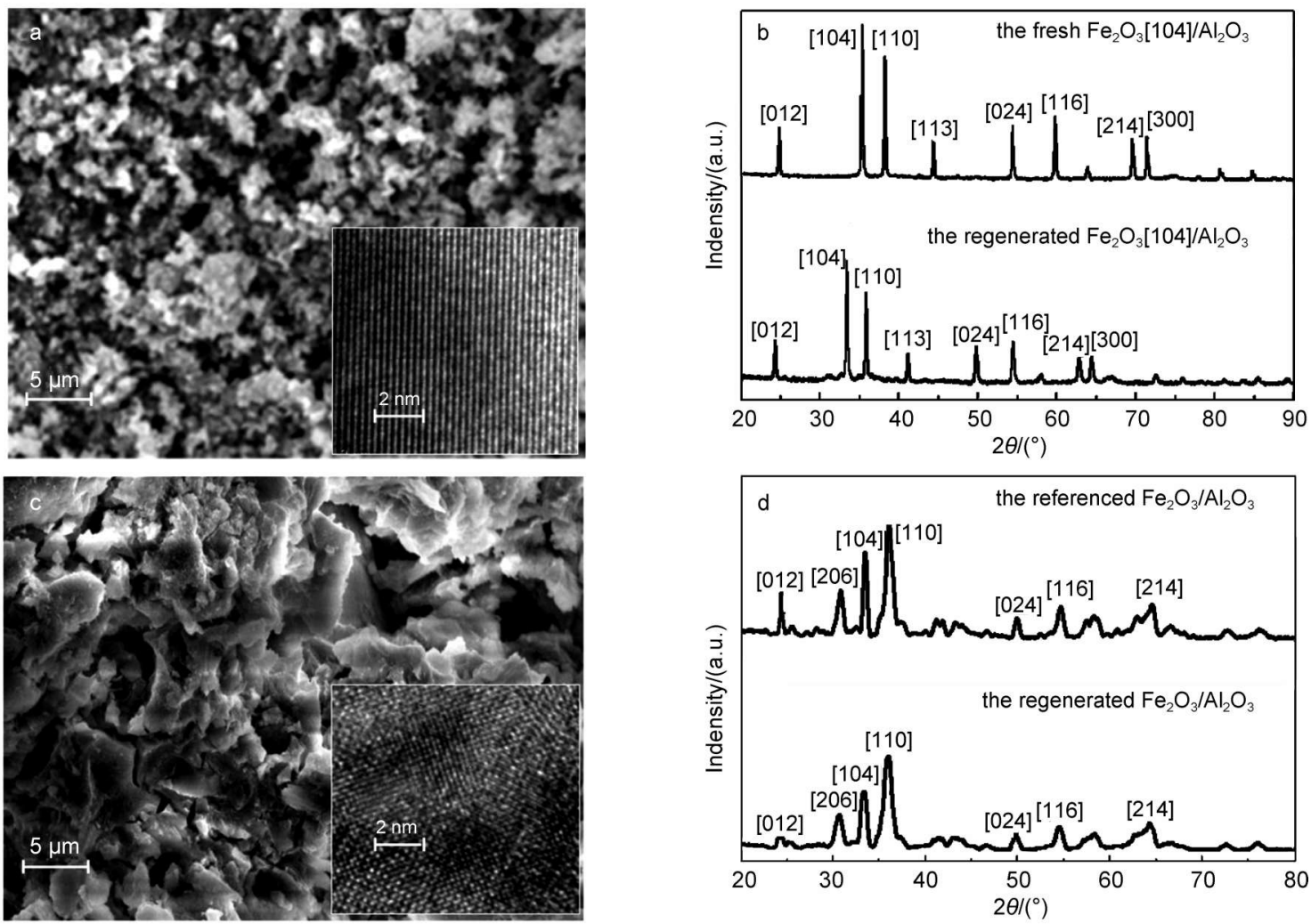

Fig.9 (a) SEM image (with the inset HRTEM image) and (b) XRD pattern of $\mathrm{Fe}_{2} \mathrm{O}_{3}[104] / \mathrm{Al}_{2} \mathrm{O}_{3}$, (c) $\mathrm{SEM}$ image (with the inset $\mathrm{HRTEM}$ image) and (d) XRD pattern of the referenced $\mathrm{Fe}_{2} \mathrm{O}_{3} / \mathrm{Al}_{2} \mathrm{O}_{3}$

$\mathrm{Al}_{2} \mathrm{O}_{3}$ and the referenced $\mathrm{Fe}_{2} \mathrm{O}_{3} / \mathrm{Al}_{2} \mathrm{O}_{3}$, which were conducted in a simultaneous thermal analyzer at $900{ }^{\circ} \mathrm{C}$. It could be observed that $\mathrm{Fe}_{2} \mathrm{O}_{3}[104] / \mathrm{Al}_{2} \mathrm{O}_{3}$ reached a conversion $(\chi)$ of $100 \%$ without carbon deposit after 4 min, implying that $\mathrm{Fe}_{2} \mathrm{O}_{3}[104]$ could be completely reduced by $\mathrm{CO}$ into metallic iron $\left(\mathrm{Fe}_{2} \mathrm{O}_{3}+3 \mathrm{CO} \rightarrow 2 \mathrm{Fe}+\right.$ $3 \mathrm{CO}_{2}$ ). Compared to $\mathrm{Fe}_{2} \mathrm{O}_{3}[104] / \mathrm{Al}_{2} \mathrm{O}_{3}$, a two-stage reaction process was identified for the referenced $\mathrm{Fe}_{2} \mathrm{O}_{3} / \mathrm{Al}_{2} \mathrm{O}_{3}$. The first stage shows a rapid rise of reaction rates at the first minute, reaching the $\chi$ of $33.3 \%$. The second reduction stage is at a relatively consistent reaction rate, showing an indicator of its poor reactivity, where the maximum $\chi$ is $72.0 \%$ and the formation of carbon should be in the ascendancy. ${ }^{50}$ Results correspond to the theoretical analysis of oxygen transfer and deep reduction above.
Five reduction-oxidation cycles were further performed to detect the effect of re-use of $\mathrm{Fe}_{2} \mathrm{O}_{3}[104] / \mathrm{Al}_{2} \mathrm{O}_{3}$ on CLC, results of which are depicted in Fig.8b. The weight loss of $2 \%$ was found after its first use, whereas, the activity differences were inconspicuous among the second to the fifth re-use of $\mathrm{Fe}_{2} \mathrm{O}_{3}[104] / \mathrm{Al}_{2} \mathrm{O}_{3}$, which implies the stability of $\mathrm{Fe}_{2} \mathrm{O}_{3}[104] / \mathrm{Al}_{2} \mathrm{O}_{3}$ for further cycles.

Fig.9 depicts the XRD patterns, SEM images, and HRTEM images of the fresh $\mathrm{Fe}_{2} \mathrm{O}_{3}[104] / \mathrm{Al}_{2} \mathrm{O}_{3}$ and the regenerated $\mathrm{Fe}_{2} \mathrm{O}_{3}$ $[104] / \mathrm{Al}_{2} \mathrm{O}_{3}$ after five reduction-oxidation cycles, in comparison with those of the referenced $\mathrm{Fe}_{2} \mathrm{O}_{3} / \mathrm{Al}_{2} \mathrm{O}_{3}$. The SEM image shows that porosity of this rough structure mainly oriented along [104] on the surface of the prepared $\mathrm{Fe}_{2} \mathrm{O}_{3}[104] / \mathrm{Al}_{2} \mathrm{O}_{3}$ according to the inset HRTEM images in Fig.9a. Fig.9b shows that all the iden- 
tified diffraction peaks of $\mathrm{Fe}_{2} \mathrm{O}_{3}$ can be assigned to $\alpha-\mathrm{Fe}_{2} \mathrm{O}_{3}$ (JCPDS card No. 33-0664), no other phase is observed, indicating a high phase purity and the well dispersion of $\mathrm{Fe}_{2} \mathrm{O}_{3}$ on the support $\mathrm{Al}_{2} \mathrm{O}_{3}$. The sharp diffraction peaks suggest good crystallinity of the prepared $\mathrm{Fe}_{2} \mathrm{O}_{3}[104] / \mathrm{Al}_{2} \mathrm{O}_{3}$ and confirm the regenerated renewable of the used $\mathrm{Fe}_{2} \mathrm{O}_{3}[104] / \mathrm{Al}_{2} \mathrm{O}_{3}$. Fig.9c shows that the surface of the referenced $\mathrm{Fe}_{2} \mathrm{O}_{3} / \mathrm{Al}_{2} \mathrm{O}_{3}$ is also porous but smoother than $\mathrm{Fe}_{2} \mathrm{O}_{3}[104] / \mathrm{Al}_{2} \mathrm{O}_{3}$, and the surface of $\mathrm{Fe}_{2} \mathrm{O}_{3} / \mathrm{Al}_{2} \mathrm{O}_{3}$ is oriented along different crystallographic directions. XRD pattern in Fig.9d verifies the high crystallization and regeneration of the referenced $\mathrm{Fe}_{2} \mathrm{O}_{3} / \mathrm{Al}_{2} \mathrm{O}_{3}$. Further, the regenerated $\mathrm{Fe}_{2} \mathrm{O}_{3}[104] / \mathrm{Al}_{2} \mathrm{O}_{3}$ and the referenced $\mathrm{Fe}_{2} \mathrm{O}_{3} / \mathrm{Al}_{2} \mathrm{O}_{3}$ keep a specific surface area of around 40 $\mathrm{m}^{2} \cdot \mathrm{g}^{-1}$ as those for the fresh $\mathrm{Fe}_{2} \mathrm{O}_{3}[104] / \mathrm{Al}_{2} \mathrm{O}_{3}$ and the fresh referenced $\mathrm{Fe}_{2} \mathrm{O}_{3} / \mathrm{Al}_{2} \mathrm{O}_{3}$.

\section{Conclusions}

We have theoretically and experimentally demonstrated that morphological control of $\mathrm{Fe}_{2} \mathrm{O}_{3}$ is very rewarding: $\mathrm{Fe}_{2} \mathrm{O}_{3}$ [104] exhibits surprisingly high activity for CO CLC and can be regenerated for further reuse. The fundamental understanding shows that morphological control of metal oxides allows preferential exposure of active sites, improves reaction activity and oxygen transfer, decreases carbon deposit during chemical looping combustion.

\section{References}

(1) Horst, J. R.; Karl, F. K. Am. Chem. Soc. 1983, 7, 71.

(2) Ishida, M.; Jin, H. Ind. Eng. Chem. Res. 1996, 35, 2469. doi: $10.1021 / \mathrm{ie} 950680 \mathrm{~s}$

(3) Fan, L. S.; Zeng, L.; Wang, W.; Luo, S. W. Energy Environ. Sci. 2012, 5, 7254. doi: 10.1039/c2ee03198a

(4) Adanez, J.; Abad, A.; Garcia-Labiano, F.; Gayan, P.; de Diego, L. F. Prog. Energy Combust. Sci. 2012, 38, 215. doi: 10.1016/j. pecs.2011.09.001

(5) Zhang, Y.; Doroodchi, E.; Moghtaderi, B. Energy Fuels 2012, 26, 287.

(6) Fang, H.; Haibin, L.; Zengli, Z. Int. J. Chem. Eng. 2009, 710515

(7) Lyngfelt, A.; Leckner, B.; Mattisson, T. Chem. Eng. Sci. 2001, 56, 3101. doi: 10.1016/S0009-2509(01)00007-0

(8) Johansson, M.; Mattisson, T.; Lyngfelt, A. J. Therm. Sci. 2006, 10, 93. doi: 10.2298/TSCI0603093J

(9) Saha, C.; Bhattacharya, S. Int. J. Chem. Eng. 2011, 36, 12048.

(10) Cho, P.; Mattisson, T.; Lyngfelt, A. Fuels 2004, 83, 1215. doi: 10.1016/j.fuel.2003.11.013

(11) Zhao, H. B.; Liu, L. M.; Wang, B. W.; Xu, D.; Jiang, L. L.; Zheng, C. G. Energy Fuels 2008, 22, 898. doi: 10.1021/ ef7003859

(12) Dennis, J. S.; Scott, S. A. Fuels 2010, 89, 1623. doi: 10.1016/j. fuel.2009.08.019

(13) Lee, J. B.; Park, C. S.; Choi, S. I.; Song, Y. W.; Kim, Y. H.; Yang, H. S. J. Ind. Engin. Chem. 2005, 11, 96.
(14) Yang, J. B.; Cai, N. S.; Li, Z. S. Energy Fuels 2007, 21, 360.

(15) Guo, L.; Zhao, H. B.; Ma, J. C.; Mei, D. F.; Zheng, C. G. Chem. Eng. Technol. 2014, 37, 1211. doi: 10.1002/ceat.v37.7

(16) Zhu, X.; Li, K. Z.; Wei, Y. G.; Wang, H.; Sun, L. Y. Fuels 2014, 28, 754. doi: 10.1021/ef402203a

(17) Wang, C. P.; Cui, H. R.; Di, H. S.; Guo, Q. J.; Huang, F. Fuels 2014, 28, 4162. doi: 10.1021/ef500354w

(18) Azimi, G.; Leion, H.; Mattisson, T.; Rydén, M.; Snijkers, F.; Lyngfelt, A. Ind. Eng. Chem. Res. 2014, 53, 10358. doi: $10.1021 / \mathrm{ie} 500994 \mathrm{~m}$

(19) Qin, W.; Wang, Y.; Dong, C.; Zhang, J.; Chen, Q.; Yang, Y. Energ. Appl. Surf. Sci. 2013, 282, 718. doi: 10.1016/j. apsusc.2013.06.041

(20) Wang, B. W.; Yan, R.; Zhao, H. B.; Zheng, Y.; Liu, Z. H.; Zheng, C. G. Energy Fuels 2011, 25, 3344. doi: 10.1021/ ef2004078

(21) Qin, W.; Chen, Q.; Wang, Y.; Dong, C.; Zhang, J.; Li, W.; Yang, Y. Energ. Appl. Surf. Sci. 2013, 266, 350. doi: 10.1016/j. apsusc.2012.12.023

(22) Wang, S. Z.; Wang, G. X.; Jiang, F.; Luo, M.; Li, H. Y. Energy Environ. Sci. 2010, 3, 1353. doi: 10.1039/b926193a

(23) Liu, L.; Zachariah, M. R. Energy Fuels 2013, 27, 4977. doi: 10.1021/ef400748x

(24) Bao, J.; Li, Z.; Cai, N. Ind. Eng. Chem. Res. 2013, 52, 6119. doi: $10.1021 / \mathrm{ie} 400237 \mathrm{p}$

(25) Ksepko, E.; Siriwardane, R. V.; Tian, H. J.; Simonyi, T.; Sciazko, M. Energy Fuels 2012, 26, 2461. doi: 10.1021/ ef201441k

(26) Moghtaderi, B.; Song, H. Energy Fuels 2010, 24, 5359.

(27) Yang, H. G.; Sun, C. H.; Qiao, S. Z.; Zou, J.; Liu, G.; Smith, S. C.; Cheng, H. M.; Lu, G. Q. Nature 2008, 453, 638. doi: 10.1038/nature06964

(28) Xie, X.W.; Li, Y.; Liu, Z. Q.; Haruta, M.; Shen, W. J. Nature 2009, 458, 746. doi: 10.1038/nature07877

(29) Zhou, X.; Xu, Q.; Lei, W.; Zhang, T.; Qi, X.; Liu, G.; Deng, K.; Yu, J. Small 2014, 10, 674. doi: 10.1002/smll.201301870

(30) Zhu, J.; Ng, K. Y. S.; Deng, D. Cryst. Growth Des. 2014, 14, 2811. doi: $10.1021 / \operatorname{cg} 5000777$

(31) Liu, X. H.; Zhang, J.; Wu, S. H.; Yang, D. J.; Liu, P.; Zhang, H. M.; Wang, S. R.; Yao, X. D.; Zhu, G. S.; Zhao, H. J. RSC $A d v$. 2012, 2, 6178. doi: 10.1039/c2ra20797d

(32) Guo, H.; Barnard, A. S. J. Colloid Interface Sci. 2012, 386, 315 doi: 10.1016/j.jcis.2012.07.011

(33) Cornell, R. M.; Schwertmann, U. The Iron Oxides: Structure, Properties, Reactions, Occurrence and Uses; Wiley-VCH: New York, USA, 2003.

(34) Dong, C. Q.; Liu, X. L.; Qin, W.; Lu, Q.; Wang, X. Q.; Shi, S. M.; Yang, Y. P. Appl. Surf. Sci. 2012, 258, 2562. doi: 10.1016/j. apsusc.2011.10.092

(35) Payne, M. C.; Teter, M. P.; Allan, D. C.; Arias, T. A.; Joannopoulos, J. D. Rev. Mod. Phys. 1992, 64, 1045. doi: 
10.1103/RevModPhys.64.1045

(36) Perdew, J. P.; Chevary, J. A.; Vosko, S. H.; Jackson, K. A.; Pederson, M. R.; Singh, D. J.; Fiolhais, C. Phys. Rev. B: Condens. Matter Mater. Phys. 1992, 46, 6671. doi: 10.1103/ PhysRevB.46.6671

(37) Leung, T. C.; Chan, C. T.; Harmon, B. N. Phys. Rev. B 1991, 44, 2923. doi: 10.1103/PhysRevB.44.2923

(38) Guo, H. B.; Barnard, A. S. Phys. Rev. B 2011, 83, 094112. doi: 10.1103/PhysRevB.83.094112

(39) Song, J. J.; Niu, X. Q.; Ling, L. X.; Wang, B. J. Fuel Process. Technol. 2013, 115, 26. doi: 10.1016/j.fuproc.2013.04.003

(40) Wong, K.; Zeng, Q. H.; Yu, A. B. J. Phys. Chem. C 2011, 115, 4656. doi: 10.1021/jp1108043

(41) Martin, G. J.; Cutting, R. S.; VauGhan, D. J.; Warren, M. C. Am. Mineral. 2009, 94, 1341. doi: 10.2138/am.2009.3029

(42) Sandratskii, L. M.; Uhl, M.; Kübler, J. J. Phys.: Condes. Matter 1996, 8, 983. doi: 10.1088/0953-8984/8/8/009

(43) White, J. A.; Bird, D. M. Phys. Rev. B: Condes. Matter Mater.
Phys. 1994, 50, 4954. doi: 10.1103/PhysRevB.50.4954

(44) Govind, N.; Petersen, M.; Fitzgerald, G.; King-Smith, D.; Andzelm, J. Comput. Mater. Sci. 2003, 28, 250. doi: 10.1016/ S0927-0256(03)00111-3

(45) Rohmann, C.; Metson, J. B.; Idriss, H. Phys. Chem. Chem. Phys. 2014, 16, 14287. doi: 10.1039/c4cp01373e

(46) Gilbert, B.; Frandsen, C.; Maxey, E. R.; Sherman, D. M. Phys. Rev. B 2009, 79, 035108. doi: 10.1103/PhysRevB.79.035108

(47) Al-Kuhaili, M. F.; Saleem, M.; Durrani, S. M. A. J. Alloy. Compd. 2012, 521, 178. doi: 10.1016/j.jallcom.2012.01.115

(48) Turkdogan, E. T.; Vinters, J. V. Metall. Trans. 1974, 5, 11.

(49) Dong, C. Q.; Sheng, S. H.; Qin, W.; Lu, Q.; Zhao, Y.; Wang, X. Q.; Zhang, J. J. Appl. Surf. Sci. 2011, 257, 8647. doi: 10.1016/j. apsusc.2011.05.042

(50) Wang, B. W.; Yan, R.; Lee, D. H.; Liang, D. T.; Zheng, Y.; Zhao, H. B.; Zheng, C. G. Energy Fuels 2008, 22, 1012. doi: 10.1021/ ef7005673 